MENEZES FILHO, A. C. P.; SANTOS, D. B.; NASCIMENTO, R. C.; OLIVEIRA, M. S.; CASTRO, C. F. S. Physicochemical evaluation and antifungal activity of essential oil from Bauhinia forficate flower Link (Fabaceae). Revista de Agricultura Neotropical, Cassilândia-MS, v. 7, n. 2, p. 57-61, abr./jun. 2020. ISSN 2358-6303.

\title{
Physicochemical evaluation and antifungal activity of essential oil from Bauhinia forficata flower Link (Fabaceae)
}

\author{
Antonio Carlos Pereira de Menezes Filho ${ }^{1}$, Douglas Braga Santos ${ }^{1}$, Ronaldo Cezar \\ Nascimento $^{1}$, Marilene Silva Oliveira ${ }^{1}$, Carlos Frederico de Souza Castro ${ }^{1}$ \\ ${ }^{1}$ Instituto Federal Goiano, Campus Rio Verde, Rio Verde, Goiás, Brasil. E-mail: astronomoamadorgoias@gmail.com, \\ douglasbragasantos@gmail.com, ronaldocesarnascimento@gmail.com, marilenes36@gmail.com, carlosfscastro@gmail.com
}

Received: 20/01/2020; Accepted: 29/03/2020.

\begin{abstract}
The essential oil of Bauhinia forficata collected in three locations, Rio Verde, Acreúna and Montividiu - GO, Brazil, had a satisfactory extraction with a yield of $0.038 ; 0.043$ and $0.046 \%$, and the relative density was $0.903 ; 0.901$ and $0.903 \mathrm{~g} \mathrm{~mL}^{-1}$, respectively, and the positive solubility in ethanol. The percentage of mycelial inhibition in vitro of the essential oil mix was more efficient for the strains of S. sclerotiorum and A. flavus. Slight growth inhibition was observed for $C$ gloeosporioides, which proved to be more resistant to essential oil concentrations used. The essential oil mix of Bauhinia forficata flowers proved to be a great option as an antifungal agent.
\end{abstract}

Keywords: Colletotrichum gloeosporioides, Bauhinia forficata, Aspergillus flavus, Sclerotinia sclerotiorum.

\section{Avaliação físico-química e antifúngica do óleo essencial da flor de Bauhinia forficata Link (Fabaceae)}

\section{RESUMO}

O óleo essencial de Bauhinia forficata coletado em três regiões, Rio Verde, Acreúna e Montividiu - GO, Brasil, apresentou bom rendimento de extração, de 0,$038 ; 0,043$ e $0,046 \%$, densidade relativa de 0,$903 ; 0,901$ e $0,903 \mathrm{~g}$ $\mathrm{mL}^{-1}$, e solubilidade positiva em etanol, respectivamente. A porcentagem de inibição micelial in vitro do mix de óleos essenciais mostrou maior sensibilidade para as cepas de Sclerotinia sclerotiorum e Aspergillus flavus. Observou-se inibição discreta no crescimento de Colletotrichum gloeosporioides, que se mostrou mais resistente às concentrações de óleo essencial utilizadas. O mix de óleos essenciais das flores de Bauhinia forficata provou ser uma ótima opção como agente antifúngico.

Palavras-chave: Colletotrichum gloeosporioides, Bauhinia forficata, Aspergillus flavus, Sclerotinia sclerotiorum. 
The genus Bauhinia has about 300 species spread throughout the tropical zones, mostly in Africa, Asia, and South America, and they are a part of folk medicine in these regions (Cagliari et al., 2018). In Brazil, a wide range of varieties of these vegetables are found in practically all biomes and the Cerrado domain. The genus Bauhinia is included in the herbal medicine, presenting species with biological actions, especially in antifungal activity. The species $B$. forficata Link. subsp. forficata, introduced in Brazil for avenues ornamentation, with arboreal size and thorny stem, semideciduous, open crown, light-colored ribbed trunk, from 5 to $9 \mathrm{~m}$ high; the leaves are simple and leathery; white flowers, arranged in axillary racemes with the characteristic aroma of essential oils (Silva et al., 2020; Nogueira and Sabino, 2012).

Essential oils are produced by plants through secondary metabolism, presenting biological, agricultural, food, and pharmaceutical actions. The synergism between the compounds that form the essential oil has high efficiency as a natural antifungal agent being used in different processes (Xavier et al., 2016). Several fungi have phytopathological action, causing high losses of production of grains, fruits, and vegetables, such as S. sclerotiorum, C. gloeosporioides e A. flavus. In this context, the present investigation was carried out to determine the physicochemical and mycelial growth inhibition activity by the essential oil of Bauhinia forficata flowers collected in three locations, against Sclerotinia sclerotiorum, Colletotrichum gloeosporioides, and Aspergillus flavus.

The physicochemical evaluation and antifungal activity experiment were carried out at the Technological Chemistry laboratory at IF Goiano, campus Rio Verde - GO, Brazil.

\section{Collection of biological material}

The flowers from individuals of Bauhinia forficata were collected from October to November 2019, in Rio Verde, Acreúna and Montividiu - GO, Brazil, with the following geographical coordinates: 17\%48'09.3''S $50^{\circ} 55^{\prime} 48.4^{\prime \prime} \mathrm{W} ; 17^{\circ} 23^{\prime} 49.6^{\prime \prime} \mathrm{S} \quad 50^{\circ} 22^{\prime} 45.7^{\prime}$ ' W and $17^{\circ} 26^{\prime} 53.0^{\prime \prime} \mathrm{S} 51^{\circ} 10^{\prime} 37.0^{\prime \prime} \mathrm{W}$, respectively. A $550 \mathrm{~g}$ aliquot of flowers were processed with $500 \mathrm{~mL}$ of distilled water. The solution was transferred to the Clevenger-type reflux apparatus for 4 hours. The hydrolate was collected and washed three times with 30 $\mathrm{mL}$ dichloromethane in a separatory funnel. The organic fraction was collected and dried with sodium sulfate. The essential oil was weighed, and the yield percentage was determined.

\section{Physicochemical analysis}

The relative density of the essential oil was determined, according to Alarcón et al. (2019). A $1 \mathrm{~mL}$ capacity pycnometer was used. The dry pycnometer was initially weighed on an analytical balance to obtain a constant weight at $25{ }^{\circ} \mathrm{C}$. Then, the essential oil was added, and weight was determined according to the equation, $\mathrm{g} \mathrm{mL}^{-1}=$ $\left[\right.$ Mass $_{\text {pycnometer }}+$ sample $)-\left(\right.$ Mass $\left.\left._{\text {pycnometer }}\right)\right](\mathrm{g}) /$ Essential oil volume $(\mathrm{mL})$. The solubility test of the essential oil by determined in an aqueous solution of ethanol $(70 \% \mathrm{v} / \mathrm{v})$, as described by Alarcón et al. (2019). In a $1.5 \mathrm{~mL}$ Eppendorf tube, $100 \mu \mathrm{L}$ of $70 \%$ (v/v) aqueous ethanol solution, and $2 \mu \mathrm{L}$ of essential oil were added, the mixture was then vortex at $100 \mathrm{rpm}$ until complete homogenization.

\section{Antifungal activity}

For antifungal activity, isolates of Sclerotinia sclerotiorum, Colletotrichum gloeosporioides, and Aspergillus flavus were used. Cultures were maintained in the PDA medium (Potato, Dextrose, Agar). The three essential oil samples were homogenized to form a "Mix".

The evaluation of the essential oil of B. forficata flowers started from concentrations of 100 (pure essential oil); $50 ; 25 ; 12.5 ; 6.25 ; 3.13$ e $1.56 \mu \mathrm{L} \mathrm{mL}^{-1}$ were used, diluted in dimethylsulfoxide (DMSO). As a negative control was used, the control sample (absence of essential oil) and DMSO, and as a positive control, the fungicide Frowncide ${ }^{\circledR}$ was used at a concentration of $10 \mu \mathrm{L} \mathrm{mL}^{-1}$.

The concentrations of the essential oils were added to the PDA culture medium as well as to the treatments with commercial fungicide and DMSO using a Drigalski spatula. After the addition of the oil concentrations, one mycelium disc of S. sclerotiorum, C. gloeosporioides, and A. flavus with $7 \mathrm{~mm}$ of diameter, was deposited separately in the center of the Petri dish. They were then incubated at the following temperatures 20,25 , and $28^{\circ} \mathrm{C}$, as described by Garcia et al. (2012), Celoto et al. (2008), and Veigas et al. (2005) adapted.

The evaluation consisted of daily colony diameter measurements using a digital caliper, 24 hours after the start of incubation. It ended when the control treatment fungal colonies entirely occupied the internal area of the plate. The percentage of mycelial growth inhibition was determined according to the equation PGI $=($ CTD CTD)/CTD*100 proposed by Garcia et al. (2012), where: PGI $=$ Percent Growth Inhibition, $\mathrm{CTD}=$ Control Treatment Diameter, CTD $=$ Chemical Treatment Diameter.

\section{Statistical analysis}

Statistical analysis consisted of triplicates for essential oil yield and quadruplicate for antifungal assay, followed by $( \pm)$ standard deviation. The means were compared by the Tukey test, with a 5\% significance level $(\mathrm{p}<0.05)$. 
Table 1 shows the physicochemical results for the three essential oils from the flower of $B$. forficata collected in different locations of the Goiás state, Brazil.

The essential oil yield of B. forficata flowers from Rio Verde, Acreúna, and Montividiu was 0.04; 0.04 and $0.05 \%$, respectively. There was no statistical difference among the three samples by the Tukey test for essential oil yield. There was homogeneity of relative density between the three samples, not differing from each other. The solubility test in ethanol was positive for all essential oil samples (Table 1).

The percentage of mycelial inhibition activities in $S$. sclerotiorum, C. gloeosporioides, and A. flavus is shown in Figure 1. Important fungicidal activity on S. sclerotiorum was observed, with percentages of inhibition between
63.08 to $83.12 \%$ in the highest concentrations, $12.5,25,50$, and $100 \mu \mathrm{L} \mathrm{mL}^{-1}$ (Figure 1). For C. gloeosporioides, the results of growth inhibition were low levels among the strains evaluated. The fungus showed little sensitivity to the synergism of the $B$. forficata essential oil mix. However, a slight inhibition was observed in the highest concentrations of 50 and $100 \mu \mathrm{L} \mathrm{mL} \mathrm{m}^{-1}$ with a growth inhibition rate of 38.64 and $51.16 \%$, respectively. For $A$. flavus, there was satisfactory inhibition efficiency between 61.11 to $66.38 \%$ at the highest concentrations of 25,50 , and $100 \mu \mathrm{L} \mathrm{mL}$. However, there was no significant difference by the Tukey test between concentrations of 25 and $50 \mu \mathrm{L} \mathrm{mL}^{-1}$. The experiment with the three strains was compared with the commercial Frowncide ${ }^{\circledR}$ fungicide at a concentration of $10 \mu \mathrm{L} \mathrm{mL}^{-1}$.

Table 1. Physicochemical properties of the essential oils obtained from the flower of Bauhinia forficata collected in three locations of the Goiás state - Brazil.

\begin{tabular}{|c|c|c|c|}
\hline Parameters & B. forficata* & B. forficata*** & B. forficata $* * *$ \\
\hline Yield (\%) & $0.04 \% \pm 0.04^{c}$ & $0.04 \% \pm 0.07^{b}$ & $0.05 \pm 0,09^{\mathrm{a}}$ \\
\hline Density $\left(\mathrm{g} \mathrm{mL}^{-1}\right) 25^{\circ} \mathrm{C}$ & $0.903 \pm 0.03^{\mathrm{a}}$ & $0.901 \pm 0.02^{\mathrm{a}}$ & $0.903 \pm 0.06^{\mathrm{a}}$ \\
\hline Solubility EtOH 70\% (v/v) & Positive & Positive & Positive \\
\hline
\end{tabular}

*Collected in Rio Verde - GO. ** Collected in Acreúna-GO. ***Collected in Montividiu - GO. Values in the average of triplicates followed by $( \pm)$ standard deviation. Different letters indicate a significant difference from the Tukey test $(\mathrm{p} \leq 0.05)$.

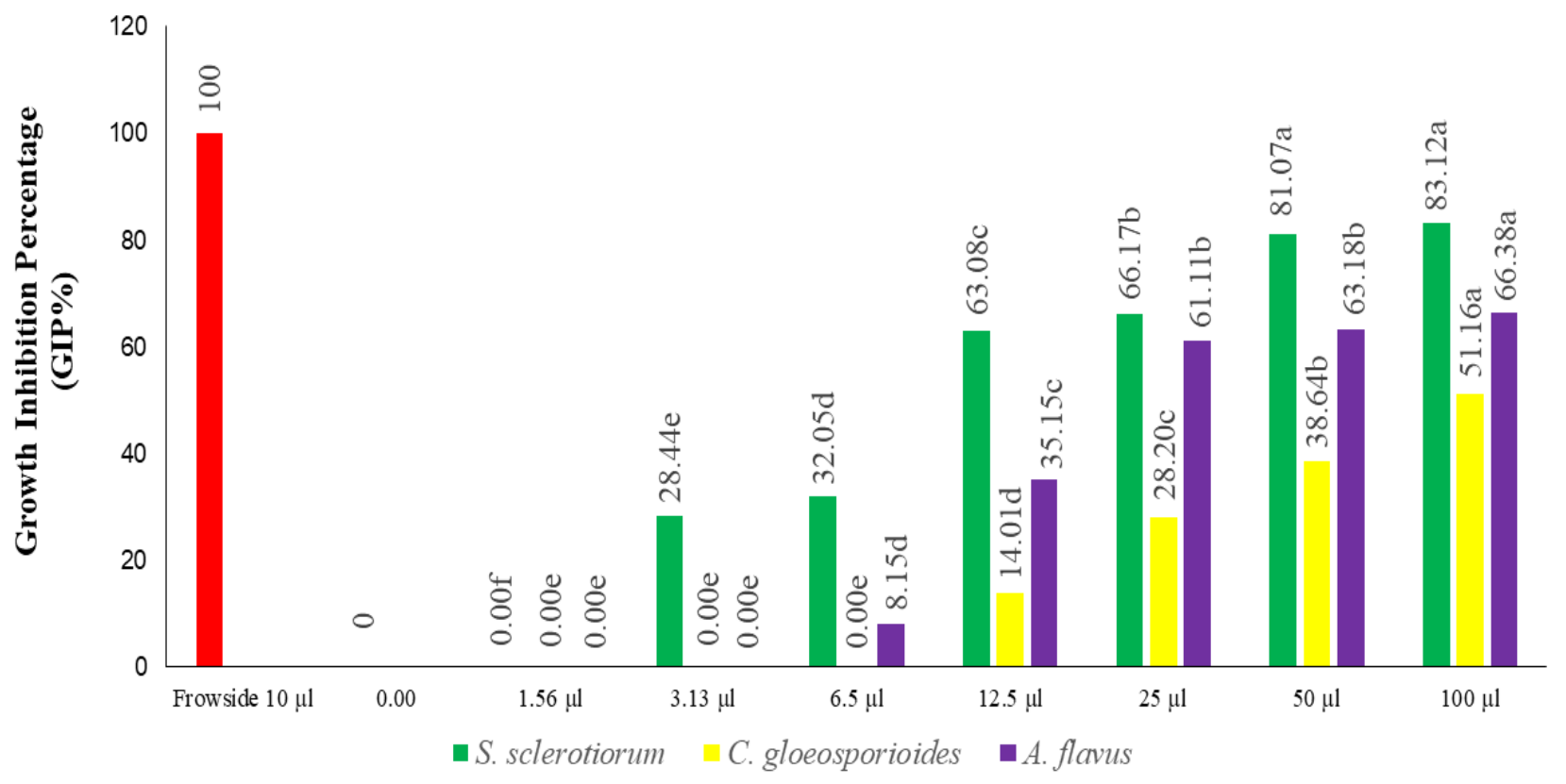

Figure 1. Growth inhibition percentage (GIP) by B. forficata flower essential oil against Sclerotinia sclerotiorum, Colletotrichum gloeosporioides, and Aspergillus flavus. Different letters for each fungal strain showed a significant difference in the Tukey test ( $\mathrm{p} \leq 0.05$ ).

S. sclerotiorum and A. flavus had higher sensitivity to essential oil concentrations of B. forficata flower. The same was not observed in C. gloeosporioides, which presented higher mycelial resistance at tested concentrations.

The germacrene $\mathrm{B}, \alpha$-pinene, $\beta$-pinene, and $E$ - $\beta$ ocimene compounds have a proven antifungal action (Macêdo Andrade et al., 2018; Ksouri et al., 2017;
Costa et al., 2010; Melo et al., 2007; Weyerstahl et al., 1988). Generally, the whole chemical composition of any essential oil should be taken into consideration because the synergistic effect between different compounds, including minority constituents, also has an effective antimicrobial action (Ksouri et al., 2017).

Valadares et al. (2018), evaluated the essential oil of the inflorescence and leaf of $P$. aduncum where they 
found inhibition activity between 85.85 to $100 \%$ and from 96.31 to $98.74 \%$, respectively, for concentrations that ranged between 10 to $50 \mu \mathrm{L} \mathrm{mL}^{-1}$. Silva et al. (2018) evaluated the essential oil of $P$. guajava leaves in two harvest periods, where they obtained mycelial inhibition efficiency against $S$. sclerotiorum, in the highest concentrations, 200 and $300 \mu \mathrm{L}$, with inhibition percentages between 90,0 to $94.9 \%$ and at the lowest concentration of $100 \mu \mathrm{L}$ from 77.5 to $80.0 \%$.

Souza Júnior et al. (2009) evaluating the mycelial inhibition in $C$. gloeosporioides with different essential oils, observed inhibition percentages from 44 to $100 \%$. Martinazzo et al. (2019) evaluated the essential oil of Cymbopogon citratus at different concentrations on the control of A. flavus. The most efficient concentrations obtained by the authors were $0.6,0.8$, and $1.0 \mu \mathrm{L}^{-1}$, with antifungal activity from 34 to $100 \%$, and at the lowest concentrations, 0.2 and $0.4 \mu \mathrm{L}^{-1}$ with inhibition between 11 and $100 \%$. Derouiche et al. (2013) evaluated the essential oil of $S$. africana flower, and they obtained high efficiency in the inhibition of A. flavus.

The essential oil of the Bauhinia forficata flower had a low extraction yield. The fungistatic effect of the "Mix" of essential oil was efficient in the three strains of fungi tested, especially for Sclerotinia sclerotiorum, followed by Aspergillus flavus and Colletotrichum gloeosporioides. Other future studies are necessary to evaluate the essential oil of Bauhinia forficata individually or in "Mix", in greenhouse environments and the field.

\section{Acknowledgments}

The authors would like to thank the Goiano Federal Institute, Campus Rio Verde; the Technological Chemistry, Natural Products, and Chemistry of Applicable Renewable Energy materials laboratories; the multiuser analytical center; to the research funding agencies CAPES, CNPq, FINEP and FAPEG, the latter for the master's degree scholarship in Agrochemicals for the first author. M.S.O. is fellow from PNPD/Capes (Universal CNPq 448297/2014-0, IF Goiano campus Rio Verde/CAPES N. 88887.342460/2019-00).

\section{Bibliographic References}

Alarcón, E.T., Conde, C.G., Méndez, G.L., 2019. Extracción, caracterización y actividad antioxidante del aceite esencial de Eucalyptus globulus Labill. Revista Cubana de Farmacia, 52(1), e266.

Cagliari, R., Kremer, F.S., Pinto, L.D.S., 2018. Bauhinia lectins: Biochemical properties and Biotechnological applications. International Journal of Biological Macromolecules, 119, 811-820.
Celoto, M.I.M., Marli, F.S.P., Sacramento, L.V.S., Celoto, F.J., 2008. Atividade antifúngica de extratos de plantas à Colletotrichum gloeosporioides. Acta Scientiarum Agronomy, 30(1), 1-5.

Costa, D.P., Filho, E.G.A., Silva, L.M.A., Santos, S.C., Passos, X.S., Silva, M.R.R., Seraphin, J.C., Ferri, P.H., 2010. Influence of fruit biotype on the chemical composition and antifungal activity of the essential oils of Eugenia uniflora leaves. Journal of the Brazilian Chemistry Society, 21(5), 851858.

Derouiche, K., Zellagui, A., Gherraf, N., Bousetla, A., Dehimat, L., Rhouati, S., 2013. Chemical composition, antimicrobial and antioxidant activities of the essential oils of Santolina africana flowers, endemic in Algeria. Journal of Bioscience and Biotechnology, 2(3), 201-206.

Garcia, R.Á., Juliatti, F.C., Barbosa, K.A.G., Cassemiro, T.A., 2012. Atividade antifúngica do óleo e extratos vegetais sobre Sclerotinia sclerotiorum. Bioscience Journal, 28(1), 48-57.

Ksouri, S., Djebir, S., Bentorki, A.A., Gouri, A., Hadef, Y., Benakhla, A., 2017. Antifungal activity of essential oils extract from Origanum floribundum Munby, Rosmarinus officinalis L. and Thymus ciliates Desf. against Candida albicans isolated from bovine clinical mastitis. Journal de Mycologie Médicale, 27(2), 245-249.

Macêdo Andrade, A.C., Rosalen, P.L., Freires, I.A., Scotti, L., Scotti, M.T., Aquino, S.G., Castro, R.D., 2018. Antifungal activity, mode of action, docking Prediction and anti-biofilm effects of (+)- $\beta$-pinene enantiomers against Candida spp. Current Tropics in Medicinal Chemistry, 18(29), 2481-2490.

Martinazzo, A.P., Oliveira, F.S., Teodoro, C.E.S., 2019. Antifungal activity of Cymbopogon citratus essential oil against Aspergillus flavus. Ciência e Natureza, 41(e20), 1-8.

Melo, R.M., Corrêa, V.F.S., Amorim, A.C.L., Miranda, A.L.P., Rezende, C.M., 2007. Identification of impact aroma compounds in Eugenia uniflora L. (Brazilian pitanga) leaf essential oil. Journal of the Brazilian Chemical Society, 18(1), 179-183.

Nogueira, A.C.O., Sabino, C.V.S., 2012. Revisão do gênero Bauhinia abordando aspectos científicos das espécies Bauhinia forficata Lin. e Bauhinia variegata $\mathrm{L}$. de interesse para a indústria farmacêutica. Revista Fitos, 7(2), 77-84.

Silva, E.A.J., Silva, V.P., Alves, C.C.F., Alves, J.M., Souchie, E.L., Barbosa, L.C.A., 2018. Chemical composition of the essential oil of Psidium guajava leaves and its toxicity against Sclerotinia sclerotiorum. Semina: Ciências Agrárias, 39(2), 865-874.

Silva, K.L.C., Silva, M.M.C., Moraes, M.M., Camara, C.A.G., Santos, M.L., Fagg, C.W., 2020. Chemical composition and acaricidal activity of essential oils from two species of the genus Bauhinia that occur in the Cerrado biome in Brazil. Journal of Essential Oil Research, 32(1), 23-31.

Souza Júnior, I.T., Sales, N.L.P, Martins, E.R., 2009. Efeito fungitóxico de óleos essenciais sobre Colletotrichum gloeosporioides, isolado do maracujazeiro amarelo. Biotemas, 22(3), 77-83. 
Valadares, A.C.F., Alves, C.C.F., Alves, J.M., Deus, I.P.B., Oliveira Filho, J.G., Santos, T.C.L., Dias, H.J., Crotti, A.E.M., Miranda, M.L.D., 2018. Essential oils from Piper aduncum inflorescences and leaves: chemical composition and antifungal activity against Sclerotinia sclerotiorum. Anais da Academia Brasileira de Ciências, 90(3), 2691-2699.

Veigas, E.C., Soares, A., Carmo, M.G.F., Rossetto, C.A.V., 2005. Toxicidade de óleos essenciais de alho e casca de canela contra fungos do grupo Aspergillus flavus. Horticultura Brasileira, 23(4), 915-919.
Xavier, M.N., Alves, J.M., Nárgella, S.C., Souchie, E.L., Silva, E.A.J., Martins, C.H.G., Ambrósio, M.A.L.V., Egea, M.B., Alves, C.C.F., Miranda, M.L.D., 2016. Composição química do óleo essencial de Cardiopetalum calophyllum Schltdl. (Annonaceae) e suas atividades antioxidante, antibacteriana e antifúngica. Revista Virtual de Química, 8(5).

Weyerstahl, P., Marshall-Weyerstahl, H., Christiansen, C., Oguntimein, B.O., Adeoye, A.O., 1988. Volatile constituents of Eugenia uniflora leaf oil. Planta Med, 54(6), 546-549. 